DOI: $10.17951 /$ lrp.2020.39.1.57-74

\author{
KATARZYNA SZYMCZYK \\ Uniwersytet Jana Kochanowskiego w Kielcach \\ Filia w Piotrkowie Trybunalskim \\ Wydział Nauk Społecznych \\ ORCID - 0000-0001-6768-7319
}

\title{
POCZĄTKI PRAKTYKI OPIEKUŃCZO-WYCHOWAWCZEJ I KSZTAŁTOWANIA SIE PUBLICZNO-PRAWNEGO SYSTEMU OPIEKI NAD DZIECKIEM W PIOTRKOWIE TRYBUNALSKIM DO 1918 ROKU
}

\begin{abstract}
Streszczenie: Troska o dzieci pozbawione opieki rodzicielskiej jest jednym z najstarszych obowiązków społeczności wobec swych najsłabszych przedstawicieli. Na przestrzeni wieków to do dzieci opuszczonych i sierocych w pierwszej kolejności kierowano działania pomocowe. Od wieków również rozwijano i doskonalono formy niesionej pomocy. Bodaj najstarsze z nich miały charakter samorzutnych inicjatyw indywidualnych bądź społecznych, jeszcze niezorganizowanych, często okazjonalnych, powodowanych ludzką empatią, niekiedy noszących znamiona biologicznego ratownictwa. Mowa tu przede wszystkim o akcjach dożywiania lub zapewnienia schronienia. Kolejne formy były związane z dobroczynną działalnością Kościoła katolickiego oraz innych organizacji najczęściej o charakterze wyznaniowym, które przejęły odpowiedzialność za najbardziej potrzebujących. Wspólne dla nich zdawało się rozumienie opieki jako aktywności społecznej o charakterze dobroczynnym i samopomocowym. Pomoc dzieciom przeważnie łączono z działalnością filantropijną bądź oświatowo-wychowawczą. Jednakże podwalin właściwie pojmowanej opieki systemowej nad najmłodszymi w Polsce możemy odnaleźć dopiero po I wojnie światowej. Niniejszy artykuł jest egzemplifikacją działalności istniejących w Piotrkowie Trybunalskim mieście o bogatej tradycji filantropijnej - najstarszych organizacji i instytucji kierujących swą pomoc do najmłodszych mieszkańców. Jest zarazem poświadczaniem słów Henryka Sienkiewicza wypowiedzianych w sprawie Macierzy Szkolnej z 1905 roku, że „[...] ofiarność polskiego społeczeństwa jest wprost niewyczerpana. Wielu przyganom może podlegać nasz narodowy charakter i sami zdajemy sobie sprawę z naszych wad i braków, gdy chodzi jednak o poświęcenie grosza dla sprawy publicznej, mało narodów nas przewyższa, a i nawet cudzoziemcy oddają nam pod tym względem sprawiedliwość”. Można sądzić, że współcześnie słowa te nie straciły aktualności.
\end{abstract}

Słowa kluczowe: opieka społeczna, dzieci, pedagogika opiekuńczo-wychowawcza 


\section{WPROWADZENIE}

Działalność na rzecz innych była od wieków stałym przejawem ludzkiej egzystencji. Zwłaszcza opieka nad dzieckiem, szczególnie porzuconym i sierocym, przez wieki była pojmowana przede wszystkim jako aktywność społeczna o charakterze dobroczynnym i samopomocowym. Przeważnie łączono ją z działalnością filantropijną bądź oświatowo-wychowawczą. Najczęściej dobroczynność przybierała charakter pomocy indywidualnej lub zorganizowanej, podejmowanej w poczuciu litości czy powinności oraz społecznej odpowiedzialności (Kępski 1991, s. 51). Dominującą formą opieki były związki samopomocy, poczynając od najstarszych mons pius (banków pobożnych) ormiańskich i rzymskokatolickich, przez stowarzyszenia kupieckie i rzemieślnicze, po towarzystwa bratniej pomocy. Oprócz tej formy samopomocy działały fundacje i zakłady fundacyjne. Te pierwsze, przeważnie zapomogowe, udzielały wsparcia ubogim, głównie w okresie przedświątecznym. Zakłady fundacyjne miały już inny charakter. Ich twórcy kierowali się przede wszystkim względami religijnymi, aczkolwiek wykazywali większe zainteresowanie losem osób potrzebujących pomocy, a zwłaszcza dzieci. Opiekę w zakładzie uzupełniano programem wychowania religijnego i zawodowego, by przygotować podopiecznych do samodzielnego życia w przyszłości.

Dopiero wraz z nadejściem rewolucji przemysłowej, jaka dokonała się w XVIII i XIX stuleciu w Europie pojawiły się znaczące przeobrażenia w dziedzinie zorganizowanej działalności socjalno-opiekuńczej (Sosnowska 2011, s. 12; por. Cutter, Sadowska 2008). Wówczas zetknęły się ze sobą religijna tradycja dobroczynności i nowoczesne koncepcje udziału państwa i osób prywatnych w organizowaniu pomocy potrzebującym. Obok dotychczas przeważającej działalności charytatywnej powstawały publiczne oraz prywatne instytucje i organizacje filantropijne. Zaczęto upowszechniać nowe praktyki pracy opiekuńczo-wychowawczej, które zapoczątkowały proces narodzin i rozwoju pedagogiki społecznej i opiekuńczej oraz przyczyniły się do powstania nowych kierunków i form dobroczynności. Dotyczy to również Polski znajdującej się wówczas w stanie politycznego niebytu. Stopniowo działania filantropijne przekształcały się w systematyczną opiekę społeczną, ukierunkowaną na wypracowanie jednolitego systemu opieki, czyli zespołu instytucji i placówek sprawujących opiekę i nadzór wychowawczy nad obywatelami w każdym wieku (Balukiewicz 2000, s. 104-106). Ale faktyczny przełom oraz modyfikację istniejących form opieki i pomocy w Polsce zapoczątkowały dopiero lata 1918-1939. Wojna i jej tragiczne skutki, a jednocześnie wzrost świadomości związanej z prawami dziecka stały się impulsem do podjęcia wielu działań nie tylko ratowniczych, ale i doskonalących system opieki. Niewystarczająca i często mało efektywna działalność filantropijna musiała być zastąpiona planową, racjonalną 
i zorganizowaną pracą społeczną. Tworzone $\mathrm{z}$ wielkim wysiłkiem ustawodawstwo socjalne, zmierzające do nadania człowiekowi praw do godnej ludzkiej egzystencji, ustanowiło jednocześnie odpowiedzialnym za ich gwarancję państwo. Niejednokrotnie samorządy terytorialne, na barkach których spoczął ciężar odpowiedzialności za codzienną realizację zadań opiekuńczo-pomocowych, nie mogły mu podołać, zwłaszcza pod względem finansowym i organizacyjnym. Stąd, najczęściej przez cały okres międzywojenny, były wspierane przez istniejące od dawna prywatne organizacje i stowarzyszenia filantropijne. Podobna sytuacja miała miejsce w Piotrkowie Trybunalskim ${ }^{1}$, gdzie przez cały okres II Rzeczypospolitej towarzystwa dobroczynne, głównie o charakterze wyznaniowym, wspomagały bądź wyręczały samorząd we wspomnianym zakresie.

\section{POCZĄTKI PIOTRKOWSKIECH DZIAŁAŃ OPIEKUŃCZYCH}

Nawiązując do początków praktyki opiekuńczo-wychowawczej w Piotrkowie należy pamiętać, że historia działalności dobroczynnej i filantropijnej w Polsce była ściśle związana z wielowiekową tradycją chrześcijańską średniowiecznej Europy. Wraz z przyjęciem chrześcijaństwa Polska znalazła się pod przemożnym wpływem kultury dobroczynności i zachodnich modeli instytucji charytatywnych i oświatowych (Cutter, Sadowska 2008, s. 79). Początkowo działalność charytatywna, najczęściej fundacyjna (Załuski 2013, s. 132; Jasiewicz 1990, s. 27; por. Fundacje i fundatorzy $w$ średniowieczu 2000), była prowadzona i wspierana przede wszystkim przez władców, instytucje kościelne: zakony, parafie oraz różnego rodzaju bractwa religijne. Stosowano wówczas dwie główne formy pomocy będące filarami miłosierdzia chrześcijańskiego. Pierwszą z nich była jałmużna, czyli drobne datki w naturze lub pieniądzu rozdawane żebrakom lub ubogim u bram klasztorów. Drugą formą - przytułki, zwane szpitalami², które wspierały ubogich, rozdzielały jałmużnę,

\footnotetext{
${ }^{1}$ Miasto Piotrków drugi człon nazwy Trybunalski zyskuje dopiero w okresie międzywojennym, stąd w pracy zastosowano pierwsze nazewnictwo.

${ }^{2}$ Ówczesne szpitale pełniły inne funkcje niż w dzisiejszym rozumieniu. Jak pisze Jan Łopato, „przytułek, zwany szpitalem, stanowił przystań życiową głównie dla ubogich starców, sierot i bezdomnych włóczęgów”. Obraz średniowiecznego szpitala w niczym nie przypominał współczesnych szpitali czy domów opieki społecznej. Jeszcze w XVIII wieku wiele szpitali (szczególnie przy parafiach wiejskich) miało tylko jedną izbę, wspólną dla mężczyzn i kobiet. Mieli oni zapewniony tylko dach nad głową, ,[...] natomiast troska o chleb codzienny, łachman na grzbiet nie opuszczała go nawet i tutaj" (Łopato 1982, s. 24). Charakter i interpretacja pojęcia szpitali zmieniła się dopiero w XIX wieku. Nastąpiło wówczas powolne oddzielenie zadań opiekuńczych i leczniczych, czyli organizacja szpitalnictwa i osobnej opieki społecznej. Uczyniło to ze szpitali centra opieki zdrowotnej, a kwestia opieki zaczęła przynależeć do zakładów opiekuńczych, dobroczynnych, które z czasem zaczęły się specjalizować. Wyodrębniono: zakłady nastawione głównie na opiekę nad chorymi,
} 
stanowiąc jednocześnie podstawowe średniowieczne instytucje charytatywne (por. Koralewski 1918; Bunsch-Konopka 1985; Cioch 2002; Leś 2001, s. 9). Również w Piotrkowie, mieście szczycącym się bogatą tradycją filantropijną, początki inicjatyw opiekuńczych są ściśle powiązane z instytucją kościoła i sięgają co najmniej pierwszego dziesięciolecia XV wieku. Na ten czas źródła datują powstanie przy parafii farnej pierwszego „szpitala”. Stał on za murami miejskimi przy drodze Krakowskiej, nad rzeką Strawką, na samym początku Przedmieścia Krakowskiego. Według tradycji fundatorem tego „domu dla starców i kalek” wraz z przynależącą doń Kaplicą Świętej Trójcy był Andrzej Szydłowski³. Fundacja zapisana na rzecz przytułku przynosiła grzywnę w wysokości 3,5 rocznego dochodu, co stanowiło niewielką sumę oraz umożliwiało utrzymanie i ewentualną opiekę zaledwie kilku lub najwyżej kilkunastu osobom (Glinkowski 1989, s. 63). Był to zapewne drewniany budynek niewielkich rozmiarów, posiadający dwie izby - po jednej dla mężczyzn i kobiet. W jego murach „[...] miejscowi i okoliczni ubodzy wsparcie, chorzy ratunek, obcy podróżni i wędrownicy gościnność i przytułek znajdowali” (Wawrzyński 1997, s. 10; Giedroyć 1908, s. 10). Inna fundacja na rzecz ubogich, tzw. dom miłosierdzia (domus misericordiae), powstała w mieście w 1699 roku. Jego zabezpieczenie ekonomiczne miała stanowić suma 3000 florenów ulokowana w pobliskich dobrach Starej Wsi. Być może u podstaw tej kolejnej organizacji dobroczynnej, podobnie jak w całym kraju na przełomie XVII/XVIII wieku, leżały potrzeby społeczne wynikające z pauperyzacji ludności, będącej z kolei wynikiem postępującego kryzysu gospodarki folwarczno-pańszczyźnianej i rozwoju przemysłu (Rybus 1989, s. 111; Leś 2001, s. 31-33; Cutter, Sadowska 2008, s. 80-81). Statystyki pochodzące z lat 1791 i 1793 podają, że spośród ludności ówczesnego Piotrkowa, liczącej 1794 osób, biedota miejska stanowiła aż 95\% społeczeństwa (Baranowski 1989, s. 85-93). W grupie tej znajdowały się oczywiście dzieci, również te pozbawione opieki rodziny, i to do tych ostatnich kierowano w pierwszej kolejności działania pomocowe.

Pierwszą instytucją w Piotrkowie, nakierowaną na potrzeby najmłodszych, była ochronka miejska im. św. Kamili, „powołana do życia w r. 1521 przez Andrzeja Szydłowskiego i Ks. Wojciecha Bryksa” (Rawita-Witanowski 1935, s. 7). Zorganizowana przy Krakowskim Przedmieściu, mieściła się w domu nr 30, bę-

starcami, dziećmi, bezdomnymi itp. Ponadto do wielu instytucji dobroczynnych wprowadzono wtedy stałą pomoc lekarską (por. Felchner 2006; Cutter, Sadowska 2008, s. 82).

${ }^{3}$ W literaturze występują nieścisłości odnośnie do dat powstania przytułku. Według Witolda Glinkowskiego miało to miejsce na początku XV wieku. Jednak wątpliwości budzi tu osoba fundatora Andrzeja Szydłowskiego, który w 1521 roku powołał do życia w Piotrkowie pierwszą ochronkę dla sierot im. św. Kamili. Nie mógł tym samym przyczynić się do założenia szpitala o całe 100 lat wcześniej (por. Glinkowski 1989, s. 63; Rawita-Witanowski 1935, s. 5; Rawita-Witanowski 1923, s. 22; Felchner 2006, s. 102). 
dącym własnością wypomnianego już przytułku dla starców i kalek. Przetrwała ponad cztery stulecia, do końca XIX wieku, jako odrębna placówka, potem zaś, po utworzeniu w mieście Towarzystwa Dobroczynności dla Chrześcijan w 1886 roku, została włączona w jego struktury. Przez długie lata przybytkiem tym zarządzały znane w środowisku lokalnym społeczniczki, siostry Felicja i Emilia Krzywickie. Przeciętnie pod ich opieką pozostawało po 115 dzieci w ciągu roku. „Niestety ochrona ta po 403 latach istnienia, wskutek «zwaloryzowania» funduszów w $1924 \mathrm{r}$. przestała działać" (Rawita-Witanowski 1935, s. 7).

W XIX stuleciu dużą wagę do kwestii zapewnienia opieki potrzebującym dzieciom przywiązywały powstające wówczas towarzystwa filantropijne i organizacje społeczne, stanowiące ważny etap rozwoju praktyki opiekuńczo-wychowawczej. Ich celem była pomoc i opieka nad różnymi kategoriami osób, działalność zaś skupiała się wokół placówek opiekuńczych lub zmierzała do utworzenia własnych zakładów (Leś 1999, s. 7-13). Towarzystwa te w doborze członków i podopiecznych kierowały się bardzo często kryterium narodowościowym. W Polsce działały one według zasad narzuconych przez państwa zaborcze i reprezentowały klika nurtów: charytatywno-oświatowy, niepodległościowy i gospodarczy (Kępski 1993, s. 63-89).

Działalność ta była traktowana jako element programu walki o wyzwolenie narodowe i postęp społeczny. Rozwój tych organizacji rozpoczęło Warszawskie Towarzystwo Dobroczynności, przez długie lata będące jedyną tego typu instytucją na ziemiach polskich. Przy ich tworzeniu ogromne znaczenie miały kwestie wyznaniowe. Należy bowiem pamiętać, że ziemie polskie były w dużym stopniu zróżnicowane pod względem religijnym, a działalność dobroczynną inspirowała nie tylko idea miłosierdzia charakterystyczna dla zachodniego chrześcijaństwa, lecz także tradycje prawosławia, judaizmu, islamu. Każda $\mathrm{z}$ tych wspólnot wyznaniowych posiadała własne instytucje dobroczynne ${ }^{4}$. Podobne zróżnicowanie charakteryzowało piotrkowską społeczność. W opisie miasta sporządzonym przez burmistrza Piotrkowa w 1820 roku widnieje podział mieszkańców na trzy grupy wyznaniowe: chrześcijan, Żydów i ,inne”; statystycznie: katolicy stanowili w Piotrkowie $48 \%$ ludności miasta, Żydzi 48\%, a ewangelicy i prawosławni $4 \%$. Proporcje te zmienia utworzenie guberni piotrkowskiej pod koniec lat 60. XIX wieku. Ponieważ odbywało się to po upadku powstania styczniowego, w okresie wzmożonej rusyfikacji Królestwa, najbardziej widoczny staje się napływ mieszkańców wyznania prawosławnego, czyli w zasadzie Rosjan. W latach 1867-1871 zwiększa

${ }^{4}$ Ze względu na heterogeniczność religijną i etniczną społeczeństwa polskiego znaczną część stowarzyszeń i większość fundacji stanowiły organizacje o charakterze wyznaniowym i narodowościowym, tj. stowarzyszenia katolickie, żydowskie i ukraińskie. Jak podaje Krzysztof Jasiewicz, niemal wszystkie fundacje miały charakter wyznaniowo-narodowościowy, tzn. z ich świadczeń mogły korzystać jedynie osoby określonej narodowości i wyznania (por. Jasiewicz 1990, s. 27). 
się on jedenastokrotnie. Przeszło dwukrotnie wzrasta też w tym czasie liczba ewangelików (Janczak 1989, s. 246-247). Tak znaczne zróżnicowanie miejskiej społeczności przełożyło się również na powoływanie i funkcjonowanie instytucji dobroczynnych o odrębnym charakterze wyznaniowym. Pierwszą z takich organizacji zrzeszająco-pomocowych był powołany do życia w maju 1868 roku Piotrkowski Oddział Rosyjskiego Towarzystwa Dobroczynności, kolejną - założoną bez mała dwadzieścia lat później - Piotrkowskie Towarzystwo Dobroczynności dla Chrześcijan (1886). Piotrkowskie Towarzystwo Pomocy dla Ubogich Wyznania Mojżeszowego diaspora żydowska utworzyła w 1894 roku. Ewangelicy zaś Towarzystwo Dobroczynne założyli dopiero w 1906 roku i o jego działalności przetrwało do naszych czasów najmniej informacji źródłowych (Samuś 1989, s. 305).

W Piotrkowie, podobnie jak w innych dużych ośrodkach (Płock, Łódź), inicjatywa utworzenia Towarzystwa Dobroczynności dla Ubogich (Rawita-Witanowski 1935, s. 5), bez względu na różnice wyznania i narodowości, zrodziła się dopiero w 1881 roku. Pomysł został zatwierdzony przez ówczesne władze rosyjskie ${ }^{5}$ po czterech latach, w dniu 10 maja 1885 roku, lecz z wyraźnym zaznaczeniem, że instytucja ma być przeznaczona wyłącznie dla chrześcijan.

Piotrkowskie Towarzystwo Dobroczynności dla Chrześcijan z chwilą rozpoczęcia działalności przy ulicy Kaliskiej (dzisiejsza ulica Juliusza Słowackiego), gdzie dawniej mieścił się Magazyn Solny, a współcześnie gmach Sądu Okręgowego, liczyło 145 członków (Rawita-Witanowski 1935, s. 5) i z czasem zaczęło przejmować istniejące już miejskie instytucje pomocowe, zapoczątkowując tym samym proces centralizacji. Brak własnej siedziby powodował, że pierwsze jego wysiłki koncentrowały się na pozyskaniu odpowiedniego lokalu, by móc skupić rozproszone po całym mieście placówki (Rawita-Witanowski 1935, s. 6-7). Udało

${ }^{5}$ W guberniach ciężar zarządzania dobroczynnością spoczywał na gubernatorach cywilnych, którzy byli zobowiązani do ścisłej współpracy z Radą Główną Opiekuńczą. Wszelkie towarzystwa dobroczynne działające poza strukturą Rady miały obowiązek informowania o swojej działalności i składania z niej sprawozdań do Rady. Na podstawie sprawozdań rad szczegółowych i innych placówek dobroczynnych Rada sporządzała raporty kwartalne o stanie funduszów i instytucji i przedkładała je Komisji Rządowej. Wszelkie kwestie sporne pomiędzy Radą Główną Opiekuńczą a Komisją Rządową Spraw Wewnętrznych i Duchownych rozstrzygała Rada Administracyjna Królestwa Polskiego. W podległości do Rady Głównej pozostawały zakłady dobroczynne prowadzone przez Kościół. Zarząd szpitalami parafialnymi należał do tzw. dozorów parafialnych, tworzonych przez dozorców - parafian i proboszcza. Szpitale te miały nazywać się domami schronienia dla starców i kalek. Opiekę nad innowiercami sprawowały odpowiednie organa - kolegia kościelne dla ewangelików i dozory bóżnicze dla Żydów. Dozory i kolegia były podporządkowane radzie szczegółowej obwodowej z danego terenu. Na mocy ukazu z dnia 19/31 czerwca 1870 roku Rada Główna Opiekuńcza i rady szczegółowe zostały zniesione. Wszystkie zakłady dobroczynne przeszły pod zarząd Ministerstwa Spraw Wewnętrznych. W następstwie powstały Rady Gubernialne Dobroczynności Publicznej (Kośka 1998, s. 275-277). 
się to w 1899 roku i odtąd stopniowo wcielane bądź nowo powoływane zakłady zajmowały przygotowywane dla nich miejsca w nowym lokum (ewentualnie poza nim). W najlepszych latach Towarzystwa (do 1914 roku) w jego strukturach działało 16 zakładów. Ostatecznie przed 1918 rokiem pod zarządem znajdowało się kilkanaście placówek opiekuńczych - 5 ochronek dla dzieci, 3 zakłady wychowawcze (w tym prawosławny św. Zofii), szwalnia (do 60 pracowników), przytułek dla starców, biblioteka (około 400 czytelników), szkółka robótek kobiecych i zakład czapniczo-krawiecki (Archiwum Państwowe w Piotrkowie Trybunalskim, sygn. 3507; sygn. 1303. Regulamin Towarzystwa Dobroczynności dla Chrześcijan). W pierwszej kolejności przejęto tanią kuchnię, czynną od 11 stycznia 1885 roku przy ulicy Kaliskiej. W połowie 1914 roku przeszła ona pod opiekę Komitetu Obywatelskiego, dostarczywszy najbiedniejszym przez cały czas swojej działalności ponad 300 tys. obiadów. W 1895 roku Rada Gubernialna Dobroczynności Publicznej oddała pod opiekę i nadzór Towarzystwa najstarszą w mieście Ochronkę nr I dla dzieci, pod nazwą św. Kamili. W 1904 roku przebywało w niej około 90 najmłodszych („Tydzień” 1904, s. 2). Kolejne, które „[...] miały całą siecią pokryć miasto” (Rawita-Witanowski 1935, s. 8), powstawały stopniowo. Ochrona nr II, założona dnia 25 lipca 1897 roku, w domu Towarzystwa przy ulicy Bykowskiej, liczyła średnio po 106 dzieci rocznie. Ochronę nr III powołano do życia w 1904 roku, pierwotnie przy ulicy Kaliskiej, a następnie przeniesiono na ulicę Sulejowską. Przeciętnie przebywało w niej 68 wychowanków. Następną Ochronę nr IV utworzono staraniem działającego w mieście Związku Katolickiego 10 września 1911 roku na Wielkiej Wsi (dzielnica miasta), przy ulicy Handlowej 16. Rocznie roztaczała opiekę nad około 60 dzieci. Kilka lat później, 1 stycznia 1915 roku, Związek Katolicki przejął ją od Towarzystwa i przeniósł siedzibę do miejskiego klasztoru oo. Bernardynów. Ochrona nr V, pierwsza tego typu placówka w dzielnicy fabrycznej, została uruchomiona w 1912 roku przy ulicy Szklanej. Przygarniała po 70 maluchów rocznie. Ostatnia w tym czasie, nr VI, założona 5 stycznia 1914 roku na Szczekanicy (dzielnica miasta), staraniem piotrkowskiej filantropki - Ludwiki Kokczyńskiej, liczyła średnio po 50 dziatwy rocznie. W wyniku działań wojennych od 1919 roku zawiesiła swą działalność (Rawita-Witanowski 1935, s. 8).

Do innych placówek opiekuńczo-wychowawczych funkcjonujących w ramach Towarzystwa (do 1915 roku) należały jeszcze dwa zakłady wychowawcze. Zakład Rodzina Adeli - zgodnie z wolą założyciela Karola Burgharda (wielki piotrkowski donator, członek honorowy Towarzystwa), przyjmowano do niego dziewczęta wyznania rzymsko-katolickiego, sieroty, w wieku od 4 do 8 lat, pochodzące z Piotrkowa lub najbliższej okolicy. Liczba wychowanek w zakładzie, aż do wyuczenia się rzemiosła czy fachu, wahała się rocznie między 7 a 12. Drugi, Zakład wychowawczy dla sierot chłopców, założony w 1909 roku w domu Towarzystwa, z funduszy 
składkowych, a zwłaszcza z zapisu Aleksandry ze Strumiłłów Bełbekowej, która na ten cel ofiarowała 200 rubli. W swojej działalności odpowiadał on zakładowi Rodziny Adeli. Średnio przebywało w nim około 18 chłopców. Trzeci zakład wychowawczy, prawosławny św. Zofii, towarzystwo wcieliło w swoje struktury w 1915 roku$^{6}$.

Towarzystwo mające nieść pomoc ludności katolickiej w wyjątkowych przypadkach, przeważnie na prośbę Magistratu, pomagało potrzebującym innych wyznań. Do wybuchu I wojny światowej, która doprowadziła finanse instytucji na skraj przepaści, dysponowało ono aktywami zabezpieczającymi działalność wszystkich placówek. W 1914 roku zostały jednak wywiezione w głąb Rosji. To, co pozostało, nie zapewniało bezpiecznej egzystencji. W wojennej zawierusze, przy ogólnym zubożeniu, malała ofiarność mieszkańców. W konsekwencji stopniowo likwidowano lub zawieszano działalność poszczególnych instytucji.

$\mathrm{Z}$ analizy wyników finansowych zakładów pomocowych wymienionych w tabeli nr 1 wynika, że wszystkie były deficytowe. Niedobory pokrywano z darowizn i zbiórek publicznych. W pierwszym półroczu 1915 roku Magistrat, na prośbę Obwodowego Komitetu Ratunkowego w Piotrkowie, przyznał Towarzystwu Dobroczynności jednorazową zapomogę wysokości 3000 koron austrowęgierskich (Piasta 2007, s. 103). Na stan finansów Towarzystwa nie miały prawie żadnego wpływu niewielkie dotacje z kasy miejskiej (w 1918 roku około 2 tys. koron) W 1922 roku z 16 placówek egzystowało już tylko 6 (Rawita-Witanowski 1935, s. 13).

\footnotetext{
${ }^{6}$ Ponadto w ramach Piotrkowskiego Towarzystwa Dobroczynności dla Chrześcijan działały jeszcze inne placówki i fundusze pomocowe, skierowane do bezrobotnych i uczącej się młodzieży, między innymi: dom pracy - założony 13 grudnia 1894 roku na bazie ustawy opracowanej przez Radę Towarzystwa; szwalnia, założona w styczniu 1898 roku w domu Towarzystwa. Dalej w 1901 roku rozpoczęła działalność szkoła robót kobiecych. Choć nauczanie w tym fachu trwało właściwie już od 1884 roku. Ponadto postarano się o „fundusz na maszyny do szycia” i „fundusz na profesyjne(!) wykształcenie”. Zapewniono „pożyczki bezprocentowe dla rzemieślników i drobnych przemysłowców". Istniał obok tego fundusz stypendialny - tylko dla wychowawców szkół piotrkowskich i to wyznania katolickiego. Funkcjonował nawet księgozbiór $z$ czytelnią. Przewidziano także „fundusz na rozmaite dobroczynne cele; fundusz na wpisy szkolne; fundusz nauczycielski im. Felicji i Emilii Krzywickich; fundusz im. Stanisława Srzednickiego na wpisy szkolne”. Oprócz wymienionych zakładów i funduszy, znajdowały się jeszcze w szafunku towarzystwa drobne kwoty, z przeznaczeniem wskazanym przez testatorów, jak fundusz analfabetów im. Walentyny Psarskiej (1867 rok) czy fundusze konserwacji pomników i grobów itp. (Archiwum Państwowe w Piotrkowie Trybunalskim, Piotrkowskie Towarzystwo Dobroczynności dla Chrześcijan, sygn. 78; Rawita-Witanowski 1935, s. 7-9).
} 
Tabela 1. Dochody i wydatki instytucji opiekuńczych działających przy Piotrkowskim Towarzystwie Dobroczynności dla Chrześcijan w latach 1914-1915 (wyliczenia podano $\mathrm{w}$ rublach $^{7}$ )

\begin{tabular}{|l|r|r|r|r|r|r|}
\hline \multirow{2}{*}{ Nazwa instytucji } & \multicolumn{2}{|c|}{ Rok 1914 } & \multirow{2}{*}{ Deficyt } & \multicolumn{2}{c|}{ Rok 1915 } & \multirow{2}{*}{ Deficyt } \\
\cline { 2 - 3 } \cline { 6 - 7 } & dochody & wydatki & & dochody & wydatki & \\
\hline Ochronka nr II & 89,18 & 354,87 & 265,69 & 7,00 & 139,00 & 132,00 \\
\hline Ochronka nr III & 145,56 & 565,40 & 419,84 & 20,09 & 325,00 & 304,91 \\
\hline Ochronka nr V & 110,25 & 655,80 & 545,55 & 7,00 & 293,00 & 286,00 \\
\hline Ochronka nr VI & 100,28 & 178,05 & 77,77 & 10,79 & 40,00 & 29,21 \\
\hline Zakład „Rodziny Adeli” & 873,60 & 1062,05 & 188,45 & 378,34 & 465,00 & 86,66 \\
\hline $\begin{array}{l}\text { Zakład opiekuńnczy } \\
\text { dla chłopców }\end{array}$ & 365,71 & $1 \mathbf{6 8 4 , 7 4}$ & 1319,03 & 6,86 & 482,50 & 475,64 \\
\hline Razem & $\mathbf{1 6 8 4 , 5 8}$ & $\mathbf{4 5 0 0 , 9 1}$ & $\mathbf{2 ~ 8 1 6 , 3 3}$ & $\mathbf{4 3 0 , 0 8}$ & $\mathbf{1 ~ 7 4 4 , 5 0}$ & $\mathbf{1 ~ 3 1 4 , 4 2}$ \\
\hline
\end{tabular}

Źródło: Archiwum Państwowe w Piotrkowie Trybunalskim, Piotrkowskie Towarzystwo Dobroczynności dla Chrześcijan, sygn. 78; 85. Budżety Piotrkowskiego Towarzystwa Dobroczynności dla Chrześcijan za lata 1914-1915, b.p.

W Piotrkowie równolegle rozwijało swoją działalność Towarzystwo Pomocy dla Ubogich Wyznania Mojżeszowego ${ }^{8}$, założone w 1894 roku przez adwokata Gustawa Lewego (Rzędowska, Hałaczkiewicz 2008, s. 145). Jednocześnie w mieście funkcjonowało Towarzystwo Dobroczynności dla Żydów, również o charakterze pomocowym. Przez lata placówki te czyniły wspólne działania wspierające społeczność żydowską, tak iż były traktowane jako jeden organ i we wszelkich materiałach źródłowych (zwłaszcza z okresu II Rzeczypospolitej) funkcjonują już jako jedna placówka pod nazwą Piotrkowskiego Towarzystwo Dobroczynności dla Żydów (Rzędowska, Hałaczkiewicz 2008, s. 146). Instytucja ta położyła ogromne zasługi w zakresie udzielania pomocy ubogiej części społeczności żydowskiej w mieście. Jako organizacja opiekuńczo-oświatowa dbała o sprawy materialno-bytowe swoich podopiecznych, chociaż nie tylko. Przy Towarzystwie działało kilka wyodrębnionych instytucji: darmowa kuchnia, Bezprocentowa Kasa Pożyczkowa „Gmiłus Cheset”, ochronka, dom sierot ${ }^{9}$. Dzięki systematycznie rosnącej liczbie

7 Dla porównania jeszcze w 1890 roku księgowy zarabiał 825 rubli rocznie, dentysta - 150, weterynarz - 360, a akuszerka - 75 . Korzec mąki pszennej w tym czasie kosztował: 2-5 rubli; w 1915 roku z uwagi na sytuację geopolityczną panowała straszna drożyzna. Korzec żyta i jęczmienia kosztował już 12,5 rubla, sól po 10 kopiejek za funt, mydło - 1 rubel (Budżety Piotrkowskiego Towarzystwa Dobroczynności dla Chrześcijan za lata 1914-1915, b.p.).

${ }^{8} \mathrm{~W}$ literaturze występuje też inna nomenklatura instytucji: Towarzystwo Pomocy Ubogim i Chorym Żydom (Rzędowska, Hałaczkiewicz 2008, s. 145; Feinkind 1930, s. 15).

9 Z kolei w latach I wojny światowej funkcjonował Komitet Ratunkowy, do 1920 roku utrzymywany z zasiłków zagranicznych (głównie amerykańskich). Warto wspomnieć niebagatelną kwotę 
działaczy i ofiarodawców rosły również fundusze, jakimi dysponowało. Pod koniec 1917 roku szacowano, że z jego pomocy korzystał co drugi Żyd zamieszkały w mieście, tj. około 6 tys. ludzi (Archiwum Państwowe w Piotrkowie Trybunalskim, Wykaz towarzystw dobroczynnych w Piotrkowie, s. 2). Oferowana pomoc przybierała najróżniejsze formy - zasiłków pieniężnych, paczek żywnościowych, odzieży i obuwia, darmowych posiłków. Towarzystwo prowadziło też dwie ochronki (przytułki), w których znalazło schronienie około 90 dzieci (Piasta 2007, s. 104).

$\mathrm{Z}$ chwilą utworzenia guberni piotrkowskiej, jednej z najbogatszych i najbardziej uprzemysłowionych w carskim imperium, w mieście następuje zauważalny rozwój demograficzny. Przybywa urzędników carskich, obsadzających najważniejsze urzędy gubernialne włącznie z Rządem Gubernialnym. Ludność napływowa to w większości Rosjanie, oczywiście wyznawcy prawosławia (Pamiatnaja Kniżka 1889, s. 17). Przybysze starali się odnaleźć w nowych warunkach, tworząc różnego rodzaju instytucje, poprzez które integrowali się wewnętrznie, zarazem oddziałując na społeczeństwo piotrkowskie. Jedną z takich organizacji zrzeszająco-pomocowych był powołany do życia w maju 1868 roku Piotrkowski Oddział Rosyjskiego Towarzystwa Dobroczynności (dalej PORTD). Od początku swego istnienia prowadził ożywioną działalność na rzecz osób poszkodowanych przez los, w tym dzieci, chociażby poprzez sprawowanie pieczy nad ochronką dla dzieci prawosławnych św. Zofii („Petrokowskoje Gubernialny je Wiedomosti”, 1873, nr 22, s. 137). Utworzono ją 17 września 1873 roku ze środków własnych Towarzystwa. Na pierwszych opiekunów wybrano Nikołaja Iwanowicza Sorokin i Natalię Stanisławowną Kierzelli. W dzień otwarcia przyjętych zostało 13 dzieci, a na koniec roku było ich już 16 . Dla większej kontroli podopiecznych przyjęto nadzorczynię Ksenię Zapolską za roczne wynagrodzenie 250 rubli. Leczenia dzieci podjął się bezpłatnie dr Anton Stanisławowicz Stryżewski. Przytułek został ulokowany w domu cerkiewnym, gdzie oddzielono na jego potrzeby 8 osobnych pomieszczeń - 4 na parterze wychodzące na ulicę i $4 \mathrm{w}$ suterynach. Zewnętrzne pomieszczenia, duże i słoneczne, były przeznaczone dla dzieci (30 miejsc), natomiast niższe na kuchnie, jadalnie i pokój dla służby (Dobrowolska 2004, s. 342-349). Jak na ówczesne realia zakład gwarantował bardzo dobre warunki dla swych podopiecznych, jednak z powodu stale przybywających dzieci z czasem i on nie spełniał warunków pod tym względem. Na początku 1877 roku w przytułku przebywało 27 dzieci (w tym 23 chłopców). W 1903 roku doliczono się już 39 podopiecznych, w grudniu 1910 roku - 41 (Dobrowolska 2004, s. 343-349). Każdy dzień w placówce zaczynał się i kończył wspólną modlitwą. Dzieci obdarzone głosem i słuchem należały do

2,5 mln rubli, jaką ofiarował Markus Braun, wykupując Żydów od pogromu planowanego przez Rosjan na sierpień 1914 roku (Rzędowska, Hałaczkiewicz 2008, s. 145). 
cerkiewnego chóru, a w czasie świąt oraz w niedzielę służyły do mszy. Dziewczynki pod kierownictwem wychowawczyni Antoniny Rogozinoj uczyły się prac domowych i rękodzielniczych, np. wiązania pończoch i koronek. Starsi zajmowali się szyciem, naprawą bielizny dla wszystkich w schronisku, pomagali kucharce w przygotowaniu jedzenia. Na działalność przytułku wydano w 1903 roku 4355 rubli. $\mathrm{Z}$ tej sumy najwięcej przeznaczono na opłacenie samej służby, tj. wychowawcy, wychowawczyni i jej pomocnicy, kucharki, praczki, stróża i piastuna; w sumie ponad 760 rubli (Dobrowolska 2004, s. 347).

Oczywiście działalność towarzystwa koncentrowała się przede wszystkim na rozdawaniu zapomóg najbiedniejszym, chociaż i sytuacja półsierot nie pozostawała mu obojętną. „Oprócz tych dzieci, którymi zajęło się towarzystwo jest jeszcze wiele innych półsierot, które utraciwszy ojców umierały w pracy nad siły, dlatego władze myślały o zwiększeniu przytułku. Aby dać dzieciom większe szanse na przyszłość, prowadzono rozmowy z fabrykantami o możliwości przyuczenia u nich chłopców do zawodu. Władze przytułku latem zapewniały swoim podopiecznym wyjazd na daczę, znajdującą się 4 wiorsty od Piotrkowa" (Pamiatnaja Kniżka 1885, s. 169; Otciet o Diejatieilnosti Petrokowskiego 1905, s. 3-12).

Dzięki przewodniczącemu, gubernatorowi gen. Ivanowi Kachanowowi (do 1884 roku), jak również organizowanym loteriom oraz przy wsparciu ze strony licznej i bogatej diaspory rosyjskiej, towarzystwo przez cały okres swej działalności dysponowało poważnymi funduszami (Dobrowolska 2004, s. 341-351; Kępski 1993, s. 213-216). Istniały plany budowy nowej siedziby przytułku przy ulicy Moskiewskiej (dzisiejsza ulica Wojska Polskiego). Nowy budynek mimo ukończenia w całości wydzierżawiono (Dobrowolska 2004, s. 347-349). Bowiem od 1912 roku sumy, jakimi dysponowało Towarzystwo, były niewystarczające na utrzymanie takiej inwestycji. Dzieci musiały niestety pozostać w wyremontowanym starym lokalu. Trudności finansowe mogły być też spowodowane zauważalną w tym okresie większą konkurencją na polu dobroczynności, gdyż istniały wówczas różnego rodzaju instytucje pomagające określonej grupie społecznej, także osobom wyznania prawosławnego. $Z$ drugiej strony nastąpił spadek stopy życiowej i niewielu było stać na sponsorowanie organizacji, co prawda działającej na rzecz dzieci, ale związanej z zaborcą. Należy pamiętać, że PORTD był może jedną z nielicznych organizacji rosyjskich $\mathrm{w}$ mieście, ale za to jedyną działającą $\mathrm{z}$ takim rozmachem wśród ludności prawosławnej. Organizacja ta realizowała swoje założenia statutowe dzięki znacznym funduszom, a także dzięki temu, że znajdowała się pod specjalną opieką gubernatorów piotrkowskich. Jednak tak bardzo aktywna za czasów carskich, musiała zawiesić swoją działalność. Po wojnie istniała nadal, ale w zmienionej formie, jako jedynie ośrodek pomagający ludności rosyjskiej. Z kolei utrzymywany z jego środków Zakład Wychowawczy dla Sierot 
Prawosławnych im. św. Zofii został w 1915 roku przejęty przez Piotrkowskie Towarzystwo Dobroczynności dla Chrześcijan. Niekorzystnie na funkcjonowaniu PORTD odbiła się ewakuacja ludności prawosławnej (urzędnicy rosyjscy i ich rodziny) oraz aresztowanie przez austriackie władze wojskowe miejscowego popa Andrzeja Karpowicza ${ }^{10}$.

Zaangażowanie w działania opiekuńczo-wychowawcze przejawiało również powstałe w 1906 roku Ewangelickie Towarzystwo Dobroczynności. Jednak spotkał je podobny los co PORTD, po wybuchu wojny jego aktywność ustała (Samuś 1989, s. 305).

Z innego typu placówek świadczących pomoc należy wymienić utworzone w 1914 roku w Piotrkowie Towarzystwo „Patronat”, zajmujące się organizowaniem opieki dla osób opuszczających więzienia oraz ich rodzin, obejmujące swym działaniem teren całej guberni piotrkowskiej. Prowadziło on także przytułek dla dzieci więźniów. W 1918 roku mieszkało tam 16 potrzebujących pomocy (Archiwum Państwowe w Piotrkowie Trybunalskim, sygn. 3507, Wykaz towarzystw, s. 2).

Jeszcze przed wybuchem I wojny światowej w mieście swój własny oddział zorganizowało Chrześcijańskie Towarzystwo Ochrony Kobiet, które utrzymywało w Piotrkowie trzy placówki ${ }^{11}$, między innymi „Ognisko rodzinne” prowadzące internat dla biednych uczennic i dysponujące 25 miejscami. Jednak i ono podzieliło los podobnych organizacji. W 1918 roku jego działalność została zawieszona z powodu braku środków. W latach 1912-1916 placówka ta zarządzała również ochronką, którą z dniem 1 stycznia 1917 roku przejął Piotrkowski Komitet Legionowej Opieki Wojennej z przeznaczeniem dla dzieci legionistów.

Czas I wojny światowej sprawił, że do rangi najważniejszego problemu urosły kwestie związane z zaspokajaniem podstawowych potrzeb mieszkańców. Wiosną 1915 roku zezwolono na organizowanie miejscowych komitetów ratunkowych, których zadania stanowiły niejako kontynuację pewnego segmentu działań funk-

${ }^{10}$ Ksiądz Andrzej Karpowicz naraził się władzom okupacyjnym, wygłaszając podczas nabożeństwa 1 kwietnia 1915 roku nieprawomyślne kazanie, po którym wezwał parafian do modłów w intencji cara i jego rodziny oraz zwycięstwa armii rosyjskiej. Przeciwko Karpowiczowi natychmiast wszczęto śledztwo i poinformowano go, że zostanie wydalony poza granice Królestwa. Jego prośba o możliwość pozostania w Piotrkowie, uzasadniana potrzebami parafian i administrowania przytułkiem św. Zofii, została odrzucona i w maju tego roku internowano go na terenie Galicji (Piasta 2007, s. 104).

${ }^{11} \mathrm{~W}$ ramach oddziału funkcjonowały jeszcze: „schronienie dla dziewcząt i młodszych kobiet poszukujących pracy” dysponujące 5 miejscami oraz „biuro pracy” pomagające w znalezieniu posady nauczycielki domowej, bony, służącej itp. Fundusze na bieżącą działalność pochodziły ze składek członkowskich, z opłat za stancje, od pracodawców (za pośrednictwo), z darowizn, wpływów z biletów wstępu na imprezy kulturalne, z projekcji filmowych i loterii (Archiwum Państwowe w Piotrkowie Trybunalskim, Akta miasta Piotrkowa, sygn. 3507, Wykaz towarzystw dobroczynnych $w$ Piotrkowie, s. 2). 
cjonujących wcześniej komitetów obywatelskich ${ }^{12}$. Zgodnie z treścią regulaminu komitetów ratunkowych celem nadrzędnym tych organizacji było „[...] umożliwienie przetrwania czasów wojny oraz staranie o utrzymanie prawidłowego biegu życia prywatnego i publicznego. [...] Zobowiązane zostały też m.in. do stwierdzenia rzeczywistych potrzeb ludności, zakładania instytucji filantropijno-społecznych i opieki nad już istniejącymi” (Piasta 2007, s. 96). Już w pierwszym roku działalności komitet założył kolejną, już dziewiątą ochronkę w mieście.

Nie bez znaczenia pozostaje fakt, że społeczność lokalna mimo ogólnego niedostatku i wielu trudności wynikających z sytuacji geopolitycznej państwa i miasta wykazywała dużą wrażliwość na niedolę drugiego człowieka, szczególnie na krzywdę najmłodszych. Na przykład z inicjatywy Józefy Żarskiej, przejętej losem sierot, zorganizowano w listopadzie 1915 roku przytułek im. Stanisława Jachowicza. Początkowo trafiło do niego sześcioro bezdomnych dzieci, jednak ich liczba szybko rosła - w marcu 1918 roku wynosiła już 33 podopiecznych, kolejnych dziesięcioro umieszczono u rodzin na wsi. Środki na podstawowe wyposażenie placówki udało się pozyskać podczas zbiórki przeprowadzonej wśród mieszkańców. Lokal placówki „[...] składał się z 3 niewielkich pokoików i kuchni dodatkowo w złym stanie technicznym, zawilgoconych i zagrzybionych, zupełnie nie nadających się na mieszkanie dla małych dzieci" (Archiwum Państwowe w Piotrkowie Trybunalskim, sygn. 3507, Wykaz towarzystw, s. 2). Wzrost liczby dzieci zmusił Zarząd przytułku do szukania dodatkowych źródeł dochodu. W 1917 roku zawarto porozumienie z władzami miasta, które przyznały na każde dziecko 20 koron miesięcznie oraz stałą zapomogę w wysokości 30 rubli miesięcznie. W zamian „sierociniec” miał obowiązek przyjmować dzieci kierowane przez Magistrat. W tym okresie trudna sytuacja gospodarcza, w tym inflacja, pochłaniały i tak skromne fundusze zakładu, podjęto więc próbę przekazania placówki miastu, na co nie uzyskano zgody. Magistrat podniósł jedynie zasiłek na dziecko do 40 koron. Podopieczni przytułku oprócz utrzymania i mieszkania mieli zapewnioną również opiekę lekarską. Stan zdrowia najmłodszych dzieci nie był jednak najlepszy, dzieci chorowały na gruźlicę, notowano także przypadki śmiertelne (Balcerek 1978, s. 61).

Trudne warunki materialne, w jakich przyszło żyć mieszkańcom Piotrkowa, powodowały, że przez cały czas wojny istniało ogromne zapotrzebowanie na instytucje wsparcia zwłaszcza dla najmłodszych. Pod nadzorem powiatowych inspektorów szkolnych znajdowały się w tym czasie oprócz szkół także inne insty-

${ }^{12}$ W Piotrkowie Komitet Obywatelski, utworzony w sierpniu 1914 roku, po ewakuacji administracji rosyjskiej, pełnił swe funkcje do czasu rozwiązania w maju 1915 roku. Komitet miał chronić mienie i życie mieszkańców, nieść pomoc materialną ofiarom wojny, rannym, chorym i bezrobotnym. Dnia 29 maja 1915 roku Komenda Obwodowa (Powiatowa) w Piotrkowie rozwiązała Komitet Obywatelski, likwidując też, za wyjątkiem opiekuńczej, wszystkie jego komisje (Piasta 2007, s. 96). 
tucje dobroczynne o charakterze opiekuńczo-wychowawczym: dziesięć ochronek, cztery zakłady wychowawcze i dwa ogródki dziecięce; Janiny Krukowskiej i Jadwigi Kwiatuszyńskiej (tzw. zakłady freblowskie).

Tabela 2 przedstawia liczbę dzieci korzystających z opieki w piotrkowskich placówkach w okresie 1915-1918.

Tabela 2. Liczba dzieci przebywających w piotrkowskich zakładach opiekuńczych w okresie 1915-1918

\begin{tabular}{|r|l|c|c|c|c|}
\hline \multirow{2}{*}{ Lp. Nazwa instytucji opiekuńczej } & \multicolumn{1}{|c|}{} & \multicolumn{3}{c|}{ Liczba dzieci w latach: } \\
\cline { 3 - 6 } & & $\mathbf{1 9 1 5}$ & $\mathbf{1 9 1 6}$ & $\mathbf{1 9 1 7}$ & $\mathbf{1 9 1 8}$ \\
\hline 1 & Ochronka PTDdlaCh** przy ul. Krakowskiej 30 & 40 & 68 & 60 & 78 \\
\hline 2 & Ochronka PTDdlaCh przy ul. Bykowskiej 75 & 71 & 80 & 67 & 70 \\
\hline 3 & Ochronka PTDdlaCh przy ul. Starowarszawskiej 2 & 70 & 70 & $*$ & $*$ \\
\hline 4 & Ochronka PTDdlaCh przy ul. Szklanej 15 & 77 & 60 & 60 & 71 \\
\hline 5 & Ochronka PTDdlaCh na Szczekanicy & $*$ & 39 & $*$ & $*$ \\
\hline 6 & Ochronka Związku Katolickiego w klasztorze oo. Bernardynów & 70 & 75 & 80 & 70 \\
\hline 7 & Ochronka Komitetu Ratunkowego & 40 & 40 & 34 & - \\
\hline 8 & Ochronka Polskiego Towarzystwa Oświatowego „Ognisko” & 50 & 50 & - & - \\
\hline 9 & Ochronka Żydowskiego Towarzystwa Dobroczynności & 76 & 76 & 79 & - \\
\hline 10 & $\begin{array}{l}\text { Zakład wychowawczy dla dziewcząt Rodziny Adeli przy ul. By- } \\
\text { kowskiej 75 }\end{array}$ & 14 & - & - & - \\
\hline 11 & Zakład wychowawczy dla sierot chłopców przy ul. Bykowskiej 75 & 20 & - & - & - \\
\hline 12 & Szwalnia - zakład wychowawczy dla dziewcząt & 70 & - & - & - \\
\hline 13 & Ogródek (Kindergarten) Jadwigi Kwiatuszyńskiej & - & 46 & - & - \\
\hline 14 & Ogródek (Kindergarten) Janiny Krukowskiej & - & 29 & - & - \\
\hline 15 & $\begin{array}{l}\text { Ochronka Piotrkowskiego Komitetu Legionowej Opieki } \\
\text { Wojennej }\end{array}$ & - & - & 30 & 30 \\
\hline 16 & Przytułek im. Stanisława Jachowicza & - & - & - & 33 \\
\hline Razem & & 621 & 410 & 352 \\
\hline
\end{tabular}

* nieczynna z powodu braku funduszy

**PTDdlaCh - Piotrkowskie Towarzystwo Dobroczynności dla Chrześcijan

Źródło: opr. własne na podstawie: APPT, Inspektorat Szkolny w Piotrkowie, sygn. 55. Wykazy zakładów opiekuńczo-wychowawczych w Piotrkowie za lata 1915-1918, b.p.

Środki na działalność pozyskiwano z różnych źródeł, przede wszystkim z kwest, darowizn organizowania zabaw tanecznych i przedstawień teatralnych. Właśnie kwestie finansowe decydowały o istnieniu tego typu placówek - brak pieniędzy sprawił, że w 1917 roku zawiesiły działalność dwie ochronki towarzystwa dla chrześcijan przy ulicy Starowarszawskiej i na Szczekanicy. W analizie ogólnej liczby dzieci korzystających z pomocy zakładów opiekuńczo-wychowawczych 
w Piotrkowie w latach 1915-1916 widać, że utrzymywały się one na stałym poziomie - od około 600 do 700. Brak danych z kilku placówek z roku 1917 i 1918 sprawił, że podane w tabeli liczby 410 i 352 powinny być powiększone przynajmniej do poziomu z roku poprzedniego (Piasta 2007, s. 107).

I wojna światowa postawiła miejskie zakłady opiekuńczo-wychowawcze w niełatwej sytuacji. Sprostanie ogromnym potrzebom piotrkowskich dzieci przy jednoczesnych trudnościach finansowych niejednokrotnie przesądzały o ich istnieniu. Pozostałe, które przetrwały, w okresie powojennym funkcjonowały już w warunkach odbudowy publiczno-prawnej opieki społecznej.

\section{PODSUMOWANIE}

Na przestrzeni wieków ukształtował się ponadkulturowy, uniwersalny pogląd, że pierwszym i naturalnym środowiskiem opiekuńczo-wychowawczym dziecka jest rodzina i przede wszystkim do niej należy troska o jego życie. Jednak w każdej epoce historycznej, w rezultacie splotu przeróżnych uwarunkowań, czy to społecznych, kulturowych, czy w wyniku zdarzeń losowych, część dzieci funkcjonowała poza rodziną lub nie znajdowała w niej możliwości zaspokojenia swych naturalnych potrzeb. Do tej grupy dzieci opuszczonych i sierocych w pierwszej kolejności kierowano różne formy pomocy zorganizowanej. Instytucjonalna opieka również w Piotrkowie Trybunalskim do 1918 roku była tworzona przy udziale trzech organizatorów: kościoła, związków wyznaniowych oraz społecznych organizacji opiekuńczych. Jednak te ostatnie najczęściej również zachowywały charakter wyznaniowy. Największy ich rozwój i duży wpływ na zapewnienie opieki piotrkowskim dzieciom miał miejsce w okresie zaborów. Wówczas to, z uwagi na położenie geopolityczne miasta będącego w tym czasie stolicą guberni piotrkowskiej, najprężniej działało rosyjskie towarzystwo dobroczynności. Co istotne do 1918 roku wszelka działalność opiekuńcza, czy to indywidualna, czy zbiorowa, była pojmowana przede wszystkim jako aktywność społeczna o charakterze dobroczynnym bądź samopomocowym. Dlatego też łączono ją przeważnie z działalnością filantropijną bądź oświatowo-wychowawczą.

Naturalnie zaspokojenie ogromu potrzeb opiekuńczych piotrkowskiej społeczności, a przede wszystkim dzieci, było wówczas niemożliwe. Stąd najczęściej dominowała orientacja związana $z$ biologicznym ratownictwem, nakierowanym na zaspokajanie podstawowych potrzeb dzieci najbiedniejszych. $Z$ kolei w odniesieniu do ludzi dorosłych przejawów filantropii doszukać się można w działaniach, najczęściej okresowych i okazjonalnych, wynikających z konkretnych potrzeb dotyczących zabezpieczeń socjalnych, niemniej podjęte w tym okresie wszelkie 
działania dobroczynne po części spełniły swoją misję, dając przyczynek do tworzenia w okresie II Rzeczypospolitej systemowej opieki nad dzieckiem i rodziną.

\section{LITERATURA}

Archiwum Państwowe w Piotrkowie Trybunalskim, Akta miasta Piotrkowa, sygn. 3507; sygn. 1303. Regulamin Towarzystwa Dobroczynności dla Chrześcijan.

Archiwum Państwowe w Piotrkowie Trybunalskim, Akta miasta Piotrkowa, sygn. 3507, Wykaz towarzystw dobroczynnych $w$ Piotrkowie.

Archiwum Państwowe w Piotrkowie Trybunalskim, Akta miasta Piotrkowa, sygn. 3931. Wykaz placówek opiekuńczo-wychowawczych w Piotrkowie.

Archiwum Państwowe w Piotrkowie Trybunalskim, Inspektorat Szkolny w Piotrkowie, sygn. 55. Wykazy zakładów opiekuńczo-wychowawczych w Piotrkowie za lata 1915-1918, b.p.

Balcerek M., 1978, Rozwój opieki nad dzieckiem w Polsce w latach 1918-1939. Warszawa, PWN.

Balukiewicz M., 2000, Protektoraty lwowskie. Początki i rozwój praktyki opiekuńczowychowawczej we Lwowie i na ziemi lwowskiej od końca XVIII stulecia do wybuchu II wojny światowej. Katowice, Wydawnictwo UŚ.

Baranowski B., 1989, Stosunki gospodarcze i społeczne w II połowie XVII i w XVIII w. W: B. Baranowski (red.), Dzieje Piotrkowa Trybunalskiego. Łódź, Wydawnictwo Łódzkie. Bunsch-Konopka H., 1985, Historia Opieki Społecznej w Polsce. W: J. Staręga-Piasek (red.), Pomoc społeczna w Polsce, cz. II. Warszawa, Centrum Medyczne Kształcenia Podyplomowego.

Cioch H., 2002, Prawo fundacyjne. Warszawa, „Difin”.

Cutter Z., Sadowska E., 2008, Opieka nad ludnościa II Rzeczypospolitej ze szczególnym uwzględnieniem mniejszości żydowskiej. W: S. Walasek (red.), Opieka nad dziećmi i młodzieżą. Studia z dziejów oświaty w XX wieku. Kraków, Oficyna Wydawnicza „Impuls”.

Dobrowolska M., 2004, Działalność Piotrkowskiego Oddziału Rosyjskiego Towarzystwa Dobroczynności Królestwie Polskim (1886-1914). „Piotrkowskie Zeszyty Historyczne", nr 6.

Feinkind M., 1930, Dzieje Żydów w Piotrkowie i okolicy od czasów najdawniejszych do chwili obecnej. Piotrków Trybunalski, [b.w.].

Felchner A., 2006, Zdrowie i zdrowotność piotrkowian. Z problematyki zdrowotności mieszkańców Piotrkowa Trybunalskiego i powiatu piotrkowskiego na tle całego kraju (od końca lat 20-tych do poczatku 70-tych XX wieku). Wrocław, Oficyna Wydawnicza Arboretum. 
Fundacje i fundatorzy w średniowieczu i epoce nowożytnej, Opaliński E., Wiślicz T. (red.), 2000. Warszawa, „Neriton” Instytut Historii Państwowej Akademii Naukowej.

Giedroyć F., 1908, Zapiski do dziejów szpitalnictwa w dawnej Polsce, Warszawa 1908, s. 3-11; cyt. za: M. Kolankiewicz, 2006, Zapiski o instytucjonalnej opiece nad dziećmi, „Dziecko Krzywdzone”, nr 17.

Glinkowski W., 1989, Układ przestrzenny, obwarowania i zabudowa miasta w XVIXVIII w. W: B. Baranowski (red.), Dzieje Piotrkowa Trybunalskiego. Łódź, Wydawnictwo Łódzkie.

Janczak J. K., 1989, Ludność. W: B. Baranowski (red.), Dzieje Piotrkowa Trybunalskiego. Łódź, Wydawnictwo Łódzkie.

Jasiewicz K., 1990, Polityka fundacyjna w II Rzeczypospolitej. „Polityka Społeczna”, nr 2. Kępski C., 1991, Dziecko sieroce i opieka nad nim w Polsce w okresie międzywojennym. Lublin, Wydawnictwo UMCS.

Kępski C., 1993, Towarzystwa dobroczynności w Królestwie Polskim (1815-1914). Lublin, Wydawnictwo UMCS.

Koralewski K., 1918, Opieka społeczna. Dobroczynność publiczna. Warszawa, Wydawnictwo B. Wierzbicki.

Kośka M., 1998, Rada Główna Opiekuńcza Szpitali, W: Archiwum Główne Akt Dawnych $w$ Warszawie. Przewodnik po zespołach, t. 2. Epoka Porozbiorowa. Warszawa, PWN.

Leś E., 1999, Działalność dobroczynna w Europie i Ameryce. Tradycje i współczesność, cz. II. Dzieje organizacji społecznych w Polsce i w krajach zachodnich. Od rewolucji przemysłowej do wybuchu II wojny światowej. Warszawa, Centrum Informacji dla Organizacji Pozarządowych Bordo.

Leś E., 2001, Zarys historii dobroczynności i filantropii w Polsce. Warszawa, Prószyński i S-ka. Łopato J., 1982, Miłosierdzie i dobroczynność w Polsce. „Polityka Społeczna”, nr 5.

Otciet o Diejatieilnosti Petrokowskiego Otdiela Russkawo Błogotworitielnowo Obściestwa w Carstwie Polskom, za 1905 gad. 1906, Piotrków.

Pamiatnaja Kniżka Petrokowskoj Guberni za 1885; 1885, Piotrków.

Pamiatnaja Kniżka Petrokowskoj Guberni za 1889 god, 1889, Piotrków.

Petrokowskoje Gubernialny je Wiedomosti, 1873, nr 22.

Piasta A., 2007, Piotrków Trybunalski w latach pierwszej wojny światowej. Piotrków Trybunalski, Naukowe Wydawnictwo Piotrkowskie.

Rawita-Witanowski M., 1923, Przewodnik po Piotrkowie Trybunalskim (z planem miasta). Piotrków Trybunalski, Wydawnictwo Oddziału Piotrkowskiego Polskiego Towarzystwa Krajoznawczego.

Rawita-Witanowski M., 1935, Dzieje Towarzystwa Dobroczynności dla Chrześcijan w Piotrkowie Trybunalskim z powodu pięćdziesięciolecia istnienia. Piotrków Trybunalski, [b.w.]. Rybus H., 1989, Regesty wybranych zapisek z akt arcybiskupów gnieźnieńskich, „Archiwa. Biblioteki. Muzea Kościelne”1961/16, s. 111, cyt za: H. Żerek-Kleszcz, Życie 
religijne i kulturalne w XVI-XVIII w. W: B. Baranowski (red.), Dzieje Piotrkowa Trybunalskiego. Łódź, Wydawnictwo Łódzkie.

Rzędowska A., Hałaczkiewicz B., 2008, Historia piotrkowskich Żydów (do 1939 roku).

Piotrków Trybunalski, nakł. Urzędu Miasta.

Samuś P., 1989, Życie społeczno-polityczne w latach 1867-1914. W: B. Baranowski (red),

Dzieje Piotrkowa Trybunalskiego. Łódź, Wydawnictwo Łódzkie.

Sosnowska J., 2011, Działalność socjalna i opiekuńcza Łódzkiego Chrześcijańskiego Towar-

zystwa Dobroczynności (1885-1940). Łódź, Wydawnictwo Uniwersytetu Łódzkiego.

Wawrzyński M., 1997, Fundacje w Polsce. Zarys historii i stan w latach dziewięćdziesiątych.

Bariery i możliwości działania. Warszawa, „Ulica Lipowa”.

$Z$ życia naszych ochronek, „Tydzień” 1904, nr 44.

Załuski M., 2013, Ustanowienie fundacji w testamencie. „Periodyk Naukowy Akademii Polonijnej”, nr 1(7).

\author{
THE BEGINNING OF CARE AND EDUCATION PRACTICE \\ AND SHAPING THE PUBLIC-LEGAL CHILD CARE SYSTEM \\ IN PIOTRKÓW TRYBUNALSKI UNTIL 1918
}

\begin{abstract}
Caring for children deprived of parental care is one of the oldest responsibilities of the community towards their weakest representatives. Over the ages it was the abandoned and orphaned children who were first placed in the aid. For the centuries its forms were also developed and improved. Supposedly the oldest of them had the character of spontaneous individual or social initiatives, yet unorganized, often occasional, caused by human empathy or heart reflexes, sometimes bearing a mark of biological rescue. Above all, it concerns alimentation and shelter. Further forms were associated with charitable activity of the Catholic Church and other organizations, most often of religious nature, that took over the responsibility for the most needy. It seemed common to them to understand care as a social activity of charitable and self-help nature. Help for children was mostly linked to philanthropic or educational activities. However, the fundamentals of properly understood systemic care over the youngest in Poland can only be traced after the First World War. The following article is an exemplification of the activities of the oldest organizations and institutions in Piotrków Trybunalski, a city of rich philanthropic tradition, directed to its youngest inhabitants. It is also an attestation to the words of Henryk Sienkiewicz said about Polska Macierz Szkolna in a year 1905 that „the sacrifice of the Polish society is simply inexhaustible. Many can be imputed to our national character and we are aware of our faults and shortcomings but when it comes to sacrificing a penny for public affairs few nations surpass us and even foreigners do justice to us in this respect". One may think these words have not lost their relevance today.
\end{abstract}

Keywords: social care, children, care and education pedagogy 